\title{
Recent advances in cultivation-independent molecular-based techniques for the characterization of vaginal eubiosis and dysbiosis
}

\author{
Ronald F. Lamont ${ }^{1,2^{*}}$ Ellen H. A. van den Munckhof ${ }^{3}$ Birgitte Møller Luef ${ }^{1}$ Christina Anne Vinter ${ }^{1}$ \\ Jan Stener Jørgensen ${ }^{1}$ \\ ${ }^{1}$ Department of Gynecology and Obstetrics, University of Southern Denmark, Institute of Clinical Research, Research Unit of Gynaecology and Obstetrics, \\ Kløvervænget 10, 10th floor, 5000 Odense C, Denmark \\ ${ }^{2}$ Division of Surgery, University College London, Northwick Park Institute of Medical Research Campus, London, HA1 3UJ, UK \\ ${ }^{3}$ DDL Diagnostic Laboratory, Visseringlaan 25, 2288 ER Rijswijk, The Netherlands
}

\begin{abstract}
"The bacterial vaginosis syndrome" has significant adverse effects for women and babies, including preterm birth and increased risk of acquisition of sexually transmitted infections and HIV. Currently, the gold standard for diagnosis is Gram stain microscopy of vaginal secretions, which is not readily available, is somewhat subjective, and does not differentiate between the likely different subtypes of vaginal dysbioses that may have different etiologies, microbiology, responses to antibiotics, and phenotypic outcomes. With new information from molecular-based, cultivation-independent studies, there is increasing interest in the use of molecular techniques for the diagnosis of bacterial vaginosis. We reviewed the current evidence on and the rationale behind the use of molecular techniques for the diagnosis of bacterial vaginosis. We found a number of commercially available molecular diagnostic tests, a few of which have US Food and Drug Administration (FDA) and/or Conformité Européenne in vitro diagnostic (CE-IVD) approval, and we have compared their performance with respect to sensitivities and specificities. Molecular-based tests have the advantage of objectivity, quantification, detection of fastidious organisms, and validity for self-obtained vaginal swabs. The performance of the molecular tests against standard microscopy is impressive, but further education of users on interpretation is needed. Bacterial vaginosis is the major cause of vaginal dysbiosis and should be recognized for the threat it is to women's genital tract health. Quantitative assessment of microbial abundance, the diversity of other organisms present, specific primers for gene sequence regions, and clades and biovars of target microbes should be recognized and incorporated into future molecular diagnostic tests to better differentiate between vaginal eubiosis and dysbiosis.
\end{abstract}

\section{Keywords}

Bacterial Vaginosis, Diagnosis, Molecular Test, Real-Time PCR, Sensitivity, Specificity, Vaginal Dysbiosis, Vaginal Eubiosis

\section{Peer Review}

The peer reviewers who approve this article are:

1. Jeff Andrews, Becton, Dickinson and Company, BD Life Sciences-Diagnostic Systems, Sparks, Maryland Competing interests: No competing interests were disclosed.

2. Jack D Sobel, Division of Infectious Diseases, Wayne State University School of Medicine, Detroit, Michigan Competing interests: No competing interests were disclosed.

3. Christina Muzny, Division of Infectious Diseases, University of Alabama at Birmingham, Birmingham, Alabama Competing interests: No competing interests were disclosed. 
*Corresponding author: Ronald F. Lamont (rflamont@icloud.com)

Competing interests: Ronald F. Lamont has advised Bayer, Becton, Dickinson and Company, Osmotech, and Symbiomix and has contributed to Scientific Meetings supported by Becton Dickinson and Hologic. Jan Stener Jorgensen has contributed to Scientific Meetings supported by Becton Dickinson and Hologic. Ellen H. A. van den Munckhof, Birgitte Møller Luef, and Christina Anne Vinter declare that they have no competing interests. Grant information: The authors declare that no grants were involved in supporting this work.

Copyright: (C) 2020 Lamont RF et al. This is an open access article distributed under the terms of the Creative Commons Attribution License, which permits unrestricted use, distribution, and reproduction in any medium, provided the original work is properly cited.

How to cite this article: Lamont RF, van den Munckhof EHA, Luef BM, Vinter CA and Jørgensen JS. Recent advances in cultivation-independent molecular-based techniques for the characterization of vaginal eubiosis and dysbiosis. Faculty Reviews 2020 9:(21) https://doi.org/10.12703/r/9-21

Published: 09 Dec 2020, Faculty Reviews 9:(21) https://doi.org/10.12703/r/9-21 


\section{Background}

Vaginal eubiosis and dysbiosis

For the purpose of this review, we have defined vaginal eubiosis as the presence in the vagina of a beneficial lactic-acid-producing microbiota, predominantly, but not uniquely, from the genus Lactobacilli. These organisms provide vaginal eubiosis inter alia through i) numerical dominance, ii) vaginal epithelial cell adhesion that prevents biofilm formation, and iii) killing ability over dysbiotic organisms through the production of lactic acid, hydrogen peroxide $\left(\mathrm{H}_{2} \mathrm{O}_{2}\right)$, and naturally occurring antimicrobials such as bacteriocins $\mathrm{s}^{1,2}$.

Vaginal dysbiosis may be defined as a prolonged deviation from a low-diversity, Lactobacillus-abundant/-dominant vaginal microbiota to a microbiota that has a high diversity and high abundance of potentially pathogenic organisms. This deviation may be due to the introduction of abnormal bacteria into the vagina and a paucity of Lactobacilli, particularly Lactobacillus crispatus, Lactobacillus jensenii, and Lactobacillus gasseri. This dysbiosis may be by sexual transmission of organisms such as Chlamydia trachomatis or Neisseria gonorrhoeae or by non-sexual transmission with organisms such as group A or G Streptococcus. Another possibility is that a pre-existing commensal such as Gardnerella vaginalis or Escherichia coli increases their virulence ${ }^{3,4}$. Finally, there may an imbalance of the normal vaginal microbiota whereby Lactobacilli are reduced in quality and/or quantity, the vaginal $\mathrm{pH}$ rises, and there is a 1,000 -fold increase in the number of other potentially pathogenic organisms such as G. vaginalis, Atopobium vaginae, Megasphaera, Sneathia, Candidatus Lachnocurva vaginae (formerly known as BV-associated bacterium [BVAB]-1) ${ }^{5}$, Mageeibacillus indolicus (formerly known as BVAB-3), Mobiluncus, and other anaerobes. This latter scenario is known as bacterial vaginosis (BV) and is the commonest cause of vaginal discharge in high-income countries, responsible for one-third of all vaginal infectious morbidity worldwide, and a major cause of adverse sequelae in obstetrics and gynecology ${ }^{7}$. Historically, BV has been poorly understood because the etiology remains unknown, the microbiology differs between subjects, the response to antibiotics differs, recurrence and resistance to treatment are common, and phenotypic outcomes of the condition vary. While historically BV has been considered by some to be a mild inconvenience for women, we now know that through human immunodeficiency virus (HIV), preterm birth (PTB), and sexually transmitted infections (STIs) it carries a significant mortality and morbidity for women and babies.

In a cross-sectional study of 394 healthy women of reproductive age, subsequently elaborated by others, the human vaginal microbial communities were classified into five community state types (CSTs): i) CST-I dominated by L. crispatus, ii) CST-II, dominated by $L$. gasseri, iii) CST-III dominated by Lactobacillus iners, iv) CST-V dominated by L. jensenii, and v) CST-IV, which has no specific dominant species and was termed the diverse group, characterized by a paucity of Lactobacilli and higher proportions of strictly anaerobic bacteria, including Prevotella, Dialister, Atopobium, Gardnerella, Megasphaera, Peptoniphilus, Sneathia, Eggerthella, Aerococcus, Finegoldia, and Mobiluncus.
CST-IV is further subdivided into CST-IVa and CST-IVb, both of which lack Lactobacilli and contain an abundance of such anaerobes or other BV-associated organisms ${ }^{8}$. Many feel that there are numerous other dysbiotic CSTs like Ravel's CST-IV, which may explain the poor understanding of BV with respect to different etiologies, microbiologies, responses to antibiotics, recurrence, and phenotypic outcomes ${ }^{7,9}$.

BV is an important condition associated with a number of adverse sequelae in both obstetrics and gynecology. In pregnancy, BV has been associated with early, late, and recurrent miscarriage, post-abortal sepsis, preterm prelabor rupture of the membranes (PPROM), postpartum endometritis, chorioamnionitis, and $\mathrm{PTB}^{7}$. In gynecology, BV has been associated with urinary tract infection, pelvic inflammatory disease, post-hysterectomy vaginal cuff infection, infertility, and acquisition of bacterial, protozoal, and viral STIs, such as herpes simplex virus (HSV), human papilloma virus (HPV), and HIV. In 1955, Gardner and Dukes' Haemophilus vaginitis (renamed BV in 1984) was considered to be nothing more than a mild inconvenience for women ${ }^{10}$, and in our experience this continues to be the case. Since $50 \%$ of women with BV are asymptomatic, this myth is perpetuated by government agencies (see https:// www.nhs.uk/conditions/bacterial-vaginosis/).

In 2012, because of concerns over increasing antibiotic resistance, and as an incentive for pharmaceutical companies to develop new antibiotics, the Generating Antibiotic Incentives Now (GAIN) Act was introduced into US law as a part of the US FDA Safety and Innovation Act. This legislation extends by 5 years, from 15 to 20 , the time in which antibiotics for serious or life-threatening infections can be sold without generic competition. The GAIN Act grants fast-track and priority review status as well as an expedited regulatory approval process to qualifying drugs ${ }^{11}$. Secnidazole, a new antibiotic used to treat $\mathrm{BV}$, was initially rejected by the FDA for processing through the GAIN Act; however, over the last 2 years, BV has been recognized as a serious or life-threatening disease that meets the criteria for fast tracking through the GAIN Act, and secnidazole is now an approved treatment for BV in the US (see https://www. catalent.com/index.php/news-events/news/Symbiomix-Therapeutics-Receives-FDA-Approval-of-Solosec-secnidazole-OralGranules-Following-Four-Year-Collaboration-with-Catalent).

Our understanding of the etiology, microbiology, therapeutic response, and recurrence following treatment and phenotypic outcome associated with $\mathrm{BV}$ is hampered by difficulty in diagnosis. As a result, self-diagnosis and self-treatment by symptomatic women are regularly employed and encouraged. In the UK, if a woman has a vaginal discharge that is abnormal for her, she generally assumes this is vulvovaginal candidiasis (VVC) until proven otherwise, despite the fact that BV is the commonest cause of vaginal discharge in high-income countries, responsible for one-third of all vaginal infectious morbidity and twice as common as VVC. In a study in three general practices in the UK, 287 asymptomatic women who attended for routine cervical cytology testing volunteered to provide an extra vaginal swab for VVC and BV analysis. Despite 
the fact that these women were asymptomatic and had attended their general practitioner's (GP's) surgery for routine cervical cytology rather than because they were symptomatic, 9\% had BV and 3.8\% had VVC. While this was not surprising, a significant percentage $(7.7 \%)$ of those with BV had taken antifungals in the previous month $(P=0.028)$, indicating wrong self-diagnosis and self-treatment ${ }^{12}$.

\section{New information from molecular techniques}

New information from molecular methods has added to our knowledge of vaginal eubiosis and dysbiosis ${ }^{7}$. By identifying organisms such as L. iners and A. vaginae that were previously under-detected and hence under-appreciated using cultivation techniques, we now know that there are different subtypes of vaginal eubiosis and dysbiosis, which may influence response to therapy and phenotypic outcome and cannot be discerned using vaginal Gram stain microscopy, the current gold standard for the diagnosis of BV. Accordingly, we need to develop and introduce novel diagnostics using molecular methods to address these shortcomings of current diagnostic techniques.

\section{Historical aspects of the diagnosis of bacterial vaginosis}

Non-molecular-based techniques

BV can be diagnosed clinically (a white/grey adherent vaginal discharge that is malodorous postmenstrually and postcoitally), by using Amsel composite clinical criteria $^{13}$, microscopically by Gram stain of vaginal secretions to determine the Nugent score $^{14-20}$, enzymatically ${ }^{21-24}$, chromatographically ${ }^{25,26}$, or using qualitative or semi-quantitative culture methods ${ }^{27}$. The pros and cons of the more commonly used techniques are shown in Table 1. The number of methods testifies to the fact that no single test is ideal, and that they can all provide false-positive and false-negative results. Several commercial point-of-care tests (POCTs) have been developed and introduced for the diagnosis of BV, though none are extensively used (Table 2).

Existing diagnostic modalities are not well served by cultivation-dependent techniques and rely upon quantitative vaginal Gram stain microscopy that suffers from a degree of subjectivity. In the UK and continental Europe, in many laboratories,

Table 1. Commonly used non-molecular tests for the diagnosis of BV.

\begin{tabular}{|c|c|c|c|}
\hline Diagnostic Test & Technique & Pros & Cons \\
\hline Amsel criteria $^{13}$ & $\begin{array}{l}\text { Identification of } \\
\text { - characteristic white-grey, homogeneous, } \\
\text { adherent vaginal discharge } \\
\text { - } \mathrm{pH}>4.5 \\
\text { - positive "whiff test"* } \\
\text { - Wet-mount microscopy to detect clue } \\
\text { cells ( } \geq 20 \% \text { per high-power field)** }\end{array}$ & $\begin{array}{l}\text { A useful point-of-care test } \\
\text { clinically }\end{array}$ & $\begin{array}{l}\text { - Irreproducible } \\
\text { - Subjective in the assessment of the } \\
\text { four composite clinical criteria }\end{array}$ \\
\hline Culture & Qualitative or semi-quantitative methods & $\begin{array}{l}\text { Detection of Gardnerella } \\
\text { vaginalis and other } \\
\text { organisms }\end{array}$ & $\begin{array}{l}\text { Lacks sensitivity and specificity, so the } \\
\text { detection of } G \text {. vaginalis on culture is } \\
\text { common in women with BV, but can also } \\
\text { be present in a significant percentage of } \\
\text { women who do not have BV }{ }^{13,28}\end{array}$ \\
\hline \multicolumn{4}{|l|}{$\begin{array}{l}\text { Vaginal } \\
\text { Gram stain } \\
\text { microscopy }\end{array}$} \\
\hline Nugent scoring ${ }^{14}$ & $\begin{array}{l}\text { Quantitative assessment of Lactobacilli, } \\
\text { G. vaginalis, and Mobiluncus spp. morphotypes } \\
\text { using Gram stain microscopy (x1,000 } \\
\text { magnification under oil-immersion) } \\
\text { A score of } \\
\text { - } 0-3=\text { normal } \\
\text { - } 4-6=\text { intermediate } \\
\text { - } 7-10=\text { BV }\end{array}$ & $\begin{array}{l}\text { Currently, the gold } \\
\text { standard for the diagnosis } \\
\text { of BV, more objective than } \\
\text { Amsel }\end{array}$ & $\begin{array}{l}\text { Needs trained and experienced } \\
\text { microscopists }\end{array}$ \\
\hline Ison/Hay method ${ }^{19}$ & $\begin{array}{l}\text { Same as Nugent but no quantitative measures } \\
\text { - Normal: lots of Lactobacilli and few other } \\
\text { morphotypes } \\
\text { - Abnormal: lots of other morphotypes and } \\
\text { few Lactobacilli } \\
\text { - Intermediate: somewhere between the two }\end{array}$ & $\begin{array}{l}\text { Simplifies Nugent scoring } \\
\text { and is increasingly used } \\
\text { in clinical practice and } \\
\text { research. } \\
\text { Doesn't require the same } \\
\text { degree of training as } \\
\text { Nugent }\end{array}$ & $\begin{array}{l}\text { - Less objective than Nugent } \\
\text { - Still requires some degree of } \\
\text { microscopy training and experience }\end{array}$ \\
\hline
\end{tabular}

* Fishy, amine odor on application of the alkali potassium hydroxide

** Vaginal epithelial cells covered with coccobacilli that obliterate the cell margins and nuclei

$\mathrm{BV}$, bacterial vaginosis; POCT, point-of-care test 
Table 2. Commercial point-of-care tests for the diagnosis of BV.

\begin{tabular}{|c|c|c|c|}
\hline $\begin{array}{l}\text { Commercial } \\
\text { point-of-care } \\
\text { test }\end{array}$ & Description & Sensitivity/specificity & Comments \\
\hline Saling glove 29 & $\begin{array}{l}\text { Fragment of narrow-range } \mathrm{pH} \\
\text { paper on the end of a finger of } \\
\text { the disposable glove }\end{array}$ & & $\begin{array}{l}\text { Useful in population-based } \\
\text { screening programs. If the } \mathrm{pH} \text { is } \\
<4.5 \text {, then it is very unlikely the } \\
\text { woman has BV. If the vaginal } \mathrm{pH} \\
\text { is } \geq 4.5 \text {, this could be due to the } \\
\text { presence of blood ( } \mathrm{pH} \sim 7.4 \text { ) or } \\
\text { semen ( } \mathrm{pH} 8.0 \text { ) but would trigger } \\
\text { further diagnostic tests for } \mathrm{BV} \text { or } \\
\text { other forms of vaginal dysbiosis. }\end{array}$ \\
\hline Electronic nose ${ }^{30}$ & $\begin{array}{l}\text { Detection of volatile organic } \\
\text { acids associated with BV by } \\
\text { passing vaginal fluid over an } \\
\text { array of specific sensors }\end{array}$ & $\begin{array}{l}\text { Compared to Gram stain microscopy: } \\
83 \% / 77 \%\end{array}$ & $\begin{array}{l}\text { Similar tests based on } \mathrm{pH} \text { and } \\
\text { trimethylamine or proline amino- } \\
\text { peptidase with mixed comparability } \\
\text { to established tests exist but have } \\
\text { failed to be introduced into regular } \\
\text { usage }^{31}\end{array}$ \\
\hline $\begin{array}{l}\text { BV Blue Test, } \\
\text { Gryphus } \\
\text { Diagnostics, } \\
\text { AL, USA }{ }^{22,32}\end{array}$ & $\begin{array}{l}\text { Chromogenic diagnostic } \\
\text { test based upon detection of } \\
\text { elevated sialidase (an enzyme } \\
\text { produced by many anaerobes) }\end{array}$ & $\begin{array}{l}\text { Good sensitivity, specificity, PPV, and NPV } \\
\text { when compared to Amsel criteria and Nugent }\end{array}$ & $\begin{array}{l}\text { Score was used clinically but failed } \\
\text { to become a widespread diagnostic } \\
\text { test for } \mathrm{BV}^{22,32}\end{array}$ \\
\hline $\begin{array}{l}\text { Affirm }{ }^{\mathrm{TM}} \text { VP III, } \\
\text { BD Diagnostics, } \\
\text { Sparks, } \\
\text { MD, USA }{ }^{31}\end{array}$ & $\begin{array}{l}\text { Quantitative DNA probe for high } \\
\text { concentrations of Gardnerella } \\
\text { vaginalis in vaginal fluid for } \\
\text { detection of Candida spp. and } \\
\text { Trichomonas vaginalis in the } \\
\text { same specimen }\end{array}$ & $\begin{array}{l}\text { Sensitivity of } 90 \% \text { and specificity of } 97 \% \\
\text { when compared with the detection of clue } \\
\text { cells. } \\
\text { Sensitivity of } 94 \% \text { and specificity of } 81 \% \\
\text { when compared to a Nugent score of } 7-10 \\
\text { on Gram stain microscopy. } \\
\text { However, since G. vaginalis can be detected } \\
\text { in up to } 55 \% \text { of women with no clinical } \\
\text { signs of BV } 13,28 \text {, the test may be most useful } \\
\text { in symptomatic patients or when used in } \\
\text { conjunction with vaginal pH and a positive } \\
\text { amine test. } \\
\text { With these additional clinical criteria, the } \\
\text { sensitivity increases to } 97 \% \text { and specificity } \\
\text { to } 71 \% \text {. }\end{array}$ & $\begin{array}{l}\text { Though it can be performed in an } \\
\text { office setting, efficiency is better } \\
\text { when carried out in the laboratory. } \\
\text { With a } 30-45 \text { minute turnaround, } \\
\text { promising results were obtained in } \\
\text { pregnant and non-pregnant women } \\
\text { as a supplement to Amsel criteria } \\
\text { and Nugent scoring } \\
\text { 31. }\end{array}$ \\
\hline
\end{tabular}

$\mathrm{BV}$, bacterial vaginosis; NPV, negative predictive value; PPV, positive predictive value

the microscopy is often performed by junior microbiology laboratory technicians who, following training and experience, are then promoted to more senior posts, and the responsibility for vaginal Gram stain diagnosis passes to new trainees. This is also probably why the PREMEVA Study provided negative results due to flaws in the diagnosis of $\mathrm{BV}$. In their protocol, the investigators recognized that Nugent scoring was rare in France and medical laboratories would require training in the technique. To standardize the diagnosis of BV using Nugent scoring, technicians in 149 laboratories in 40 centers across France were given a training video, a technical brochure, and "training slides", but no further details were provided. There was a significant delay of 5 years from presentation in abstract form in 2013 at the SMFM meeting to publication in 2018. In 2015, one of the PREMEVA co-authors admitted that the reason for the delay was because of concerns about the diagnosis of BV by Gram stain (personal communication to R.F.L. and J.S.J.). Their intention was to repeat the diagnosis using molecular diagnostic methods (personal communication to R.F.L. and J.S.J.), but in the published paper, this was not the case. Accordingly, this emphasizes that there is a need for a more robust and objective diagnostic test for vaginal eubiosis and dysbiosis.

\section{Molecular-based techniques}

The background to the development and introduction of molecular-based diagnostic tests for the diagnosis of $\mathrm{BV}$ has been reviewed excellently elsewhere ${ }^{31}$. Together with a number of subsequent studies that have been supportive of the developments over traditional methods of diagnosing $\mathrm{BV}^{33-36}$, advances have been made, albeit they may be complementary to, rather than replace, culture-based techniques ${ }^{37}$. These can be summarized as follows. Using species-specific primers in 27 women with $\mathrm{BV}$, and 46 without $\mathrm{BV}$, a total of eight different bacteria were significantly associated with $\mathrm{BV}(P<0.001)$. These were BVAB-1 (now proposed to be renamed Candidatus Lachnocurva vaginae) $^{5}$, BVAB-2, BVAB-3 (now renamed M. indolicus) ${ }^{6}$, 
Gardnerella, Leptotrichia, Megasphaera, and Atopobium species, and Eggerthella-like uncultured bacterium. With a few exceptions, the combination of bacterium-specific polymerase chain reaction (PCR) assays did not substantially improve sensitivity or specificity ${ }^{38}$. In a follow up study that addressed the diagnostic accuracy of these target organisms tested against Amsel criteria and Nugent score, PCR detection of one or more of these fastidious organisms was a more reliable indicator of BV than the presence of G. vaginalis alone (Table 3) ${ }^{39}$. Using Nugent score to classify 231 vaginal samples, quantitative real-time PCR using specific primers identified $G$. vaginalis, Lactobacillus species, Mobiluncus curtisii, A. vaginae, and M. hominis. Twenty samples were classified as BV, 44 as intermediate, and 167 as normal microbiota. Qualitative PCR comparisons between women with and without BV for these organisms are demonstrated in Table 4. Median concentrations of A. vaginae, G. vaginalis, $M$. curtisii, and M. hominis were significantly higher, and median concentration of Lactobacilli species was significantly lower in women with BV compared to those without ${ }^{40}$. To optimize the molecular methods for

Table 3. Sensitivities and specificities of individual or combined organisms for the detection of bacterial vaginosis using molecular techniques ${ }^{38,39}$.

\begin{tabular}{|c|c|c|c|}
\hline Organism & Sensitivity & Specificity & Comments \\
\hline BVAB-1* & - & $97.8 \%$ & \\
\hline BVAB-2 & - & $95.7 \%$ & \\
\hline BVAB-3** & - & $97.8 \%$ & \\
\hline Gardnerella vaginalis & $100 \%$ & $41 \%$ & \\
\hline Leptotrichia & - & $95.7 \%$ & \\
\hline BVAB-1 \& BVAB-3 & - & $100 \%$ & \\
\hline BVAB-1 \& Megasphaera & $100 \%$ & - & \\
\hline Megasphaera \& one BVAB spp. & $99 \%$ & $89 \%$ & Tested against Amsel criteria \\
\hline Megasphaera \& one BVAB spp. & $95.9 \%$ & $95.7 \%$ & Tested against Nugent score \\
\hline
\end{tabular}

BVAB, bacterial vaginosis-associated bacterium

* BVAB-1 now proposed to be renamed Candidatus Lachnocurva vaginae

** BVAB-3 has been re-named Mageeibacillus indolicus ${ }^{\natural}$

Table 4. Qualitative and quantitative polymerase chain reaction analysis of organisms for the prediction of $\mathrm{BV}^{40}$.

\begin{tabular}{|c|c|c|c|c|c|c|c|}
\hline Organism & $\begin{array}{l}\text { BV positive (\%) } \\
(n=20)\end{array}$ & $\begin{array}{l}\text { BV negative (\%) } \\
(n=167)\end{array}$ & Sensitivity & Specificity & PPV & NPV & $P$-value \\
\hline \multicolumn{8}{|l|}{ Qualitative } \\
\hline Gardnerella vaginalis & $19(95 \%)$ & $116(69 \%)$ & & & & & 0.001 \\
\hline Atopobium vaginae & $19(95 \%)$ & $79(47 \%)$ & & & & & 0.001 \\
\hline Mobiluncus curtisii & $13(65 \%)$ & $21(13 \%)$ & & & & & 0.001 \\
\hline Mycoplasma hominis & $10(50 \%)$ & $22(13 \%)$ & & & & & 0.001 \\
\hline Lactobacilli & $12(60 \%)$ & $141(84 \%)$ & & & & & 0.007 \\
\hline \multicolumn{8}{|l|}{${ }^{*}$ Quantitative } \\
\hline G. vaginalis $>10^{9}$ & & & $90 \%$ & $99 \%$ & $14 \%$ & & \\
\hline A. vaginae $>10^{8}$ & & & $50 \%$ & $100 \%$ & $19 \%$ & & \\
\hline M. curtisii $>10^{5}$ & & & $45 \%$ & $100 \%$ & $38 \%$ & & \\
\hline M. hominis $>10^{6}$ & & & $30 \%$ & $98 \%$ & $38 \%$ & & \\
\hline Lactobacilli >10 8 & & & $44 \%$ & $100 \%$ & $8 \%$ & & \\
\hline
\end{tabular}

*Adjusted for quantitation

BV, bacterial vaginosis; NPV, negative predictive value; PPV, positive predictive value 
routine practice, an adjusted quantification was made by creating a threshold DNA level for the five organisms listed, and their predictive values are illustrated in Table 4. When the area under the curve (AUC) from the receiver operating characteristic (ROC) curves for bacterial molecular counts were applied prospectively for validation in 56 pregnant women, the negative predictive value (NPV) was $96 \%$ and the positive predictive value (PPV) was $99 \%$.

\section{The combination of $A$. vaginae and $G$. vaginalis for the diagnosis of bacterial vaginosis}

A. vaginae, in some habitats where sugars are a scarce source of energy, produces significant quantities of ammonia through peptidyl-peptidase activity. Prevotella bivia (formerly Bacteroides bivia) also produces ammonia, and this acts as a substrate to promote the growth of $G$. vaginalis ${ }^{41-43}$. Accordingly, since A. vaginae and $G$. vaginalis are frequently detected in association with $\mathrm{BV}$, a number of authors examined the possibility of combining these two organisms as a means of diagnosing $\mathrm{BV}^{38,40,44-46}$. Using species-specific PCR for $G$. vaginalis and A. vaginae after obtaining 145 vaginal samples from healthy pregnant and non-pregnant women, researchers found that the comparative ROC analysis was poor, with an accuracy of 63-68\%. In contrast, detection of the simultaneous presence of A. vaginae and $G$. vaginalis to diagnose BV had an accuracy of $87.8 \%$ ( $P<0.001)$, a sensitivity of $78 \%$, and a specificity of $98 \%{ }^{46}$. In another study, A. vaginae and $G$. vaginalis were highly sensitive for BV (sensitivities $96 \%$ and 99\%, respectively), but $A$. vaginae was more specific than $G$. vaginalis (specificities $77 \%$ and $35 \%$, respectively). A. vaginae was rarely detected without $G$. vaginalis, and in women in whom both organisms were detected, there were higher rates of recurrence $(83 \%)$ than in women infected with G. vaginalis alone ${ }^{47}$. Ninety-six clinical samples sent for $\mathrm{BV}$ diagnosis were tested for A. vaginae, G. vaginalis, M. mulieris, and Bacteroides fragilis using realtime PCR. Twenty-eight samples (29\%) contained A. vaginae, 26 of which $(93 \%)$ also contained $G$. vaginalis. In the 68 samples without A. vaginae, only 7 (10\%) contained G. vaginalis $^{45}$. Using a quantitative threshold, 19/20 BV samples had a DNA level for either $A$. vaginae of $\geq 10^{8}$ copies $/ \mathrm{mL}$ or G. vaginalis of $\geq 10^{9}$ copies $/ \mathrm{mL}$ and $9 / 20$ had both. The combination of an $A$. vaginae DNA level of $\geq 10^{8}$ copies $/ \mathrm{mL}$ and a G. vaginalis DNA level of $\geq 10^{9}$ copies $/ \mathrm{mL}$ demonstrated the best predictive criteria for the diagnosis of $\mathrm{BV}$ with excellent sensitivity (95\%), specificity (99\%), NPV (99\%), and PPV $(95 \%)^{40}$.

\section{Current commercially available molecular tests for the diagnosis of bacterial vaginosis in the USA and the European Union}

New technologies employing molecular markers for BV have been developed to overcome the problems associated with the Amsel criteria, vaginal Gram stain microscopy, and POCTs. Molecular tests have the advantage of i) objectivity, ii) quantification, iii) detection of fastidious organisms, and iv) validity for self-obtained vaginal swabs. The techniques are dependent upon the detection of specific bacterial nucleic acids and are primarily available as direct probe assays, as already mentioned $^{31}$, or nucleic acid amplification test (NAAT) assays. The commonest target for the identification of bacteria using molecular-based techniques is the small ribosomal subunit of the 16S rRNA gene, which is useful because it is present in all bacteria and has regions of conserved sequence that can be targeted by universal (broad-range), or specific primers. It also has areas of heterogeneity that can be used to identify bacteria or to infer phylogenetic relationships through comparisons with known organisms in sequence databases ${ }^{7}$. The 16S rRNA gene has a length of approximately 1,540 nucleotides and contains nine hypervariable regions: V1 to V9. These hypervariable regions exhibit variable degrees of sequence diversity among different bacterial genera. The $\mathrm{V} 1-\mathrm{V} 2, \mathrm{~V} 3-\mathrm{V} 4$, or $\mathrm{V} 4$ regions are most often targeted in microbiota studies. Universal PCR primer sets are designed to amplify as many different $16 \mathrm{~S}$ rRNA gene sequences from a wide range of bacterial species as possible. However, there are no suitable $100 \%$ conserved regions of the 16S rRNA gene available for PCR amplification ${ }^{48}$.

Commercially available molecular diagnostic tests for the diagnosis of bacterial vaginosis currently used in the USA Currently in the USA, there are a number of tests for the molecular diagnosis of $\mathrm{BV}$ in symptomatic women, most if not all of which are multiplex PCR assays. While some of these laboratories have a small throughput, to our knowledge, there are five commercially available molecular diagnostic tests for the diagnosis of $\mathrm{BV}$ that dominate the market in the USA ${ }^{49,50}$, two of which are FDA cleared ${ }^{50,51}$ : i) NuSwab (Laboratory Corporation of America Holdings, Burlington, NC, USA) ${ }^{49}$, ii) SureSwab (Quest Diagnostics, Secausus, NJ, USA), iii) BD MAX ${ }^{\mathrm{TM}}$ Vaginal Panel (VP) (Becton Dickinson, Sparks, MD, USA) ${ }^{51}$, iv) MDL BV Panel (Medical Diagnostics Laboratory, Hamilton Township, NJ, USA), and v) Hologic Aptima ${ }^{\circledR}$ BV Assay (Hologic Inc., San Diego, CA, USA) ${ }^{50}$. These are NAATs that are capable of detecting as little as one organism per sample. In a short period of time, specific nucleic acid sequences are enzymatically amplified exponentially to produce billions of copies of the sequences. The amplified products are detected and identified. Such real-time PCRs eliminate the need for post-amplification analysis and reduce the risks of contamination. The bacteria that are positive or negative predictors of $\mathrm{BV}$ and other microorganisms detected in the various tests and the test characteristics and comparator standards are listed in Table 5 and Table 6 , respectively.

The NuSwab detects A. vaginae, BVAB-2, and Megasphaera spp., which are predictive of $\mathrm{BV}$, and $L$. crispatus, which is a negative predictor of $\mathrm{BV}^{7}$. G. vaginalis was not included because $G$. vaginalis can be detected in up to $55 \%$ of women with no clinical signs of $\mathrm{BV}^{13,28}$. An extended version detects i) Candida albicans; ii) Candida glabrata; iii) C. trachomatis, iv) N. gonorrhea. and v) Trichomonas vaginalis (TV) ${ }^{52}$ (see https://files.labcorp.com/testmenu/180021.pdf).

The SureSwab detects i) G. vaginalis, ii) A. vaginae, and iii) Megasphaera spp. as positive predictors of $\mathrm{BV}$ and iv) L. crispatus, v) L. acidophilus, and vi) L. jensenii as negative predictors of BV. Sensitivity, specificity, PPV, and NVP were 

Table 5 . The bacteria and other microorganisms detected and used to diagnose BV and other causes of
vaginal dysbiosis.

\begin{tabular}{|c|c|c|c|c|c|c|}
\hline & NuSwab** & SureSwab & $\begin{array}{c}\text { BD MAX } \\
\text { Vaginal Panel }\end{array}$ & $\begin{array}{l}\text { MDL BV } \\
\text { Panel }\end{array}$ & AmpliSens ${ }^{*}$ & $\begin{array}{l}\text { Hologic } \\
\text { Aptima BV }\end{array}$ \\
\hline \multicolumn{7}{|c|}{ POSITIVE PREDICTORS OF BV } \\
\hline Atopobium vaginae & $\checkmark$ & $\checkmark$ & $\checkmark$ & $\checkmark$ & $\checkmark$ & $\checkmark$ \\
\hline Gardnerella vaginalis & & $\checkmark$ & $\checkmark$ & $\checkmark$ & $\boldsymbol{J}^{*}$ & $\checkmark$ \\
\hline $\begin{array}{l}\text { Megasphaera spp. } \\
\text { (types } 1 \text { or } 2 \text { ) }\end{array}$ & $\checkmark$ & $\checkmark$ & $\checkmark$ & $\checkmark$ & & \\
\hline BVAB2 & $\checkmark$ & & $\checkmark$ & & & \\
\hline \multicolumn{7}{|c|}{ NEGATIVE PREDICTORS OF BV } \\
\hline Lactobacillus acidophilus & & $\checkmark$ & & & * & \\
\hline Lactobacillus crispatus & $\checkmark$ & $\checkmark$ & $\checkmark$ & & * & $\checkmark$ \\
\hline Lactobacillus jensenii & & $\checkmark$ & $\checkmark$ & & * & $\checkmark$ \\
\hline Lactobacillus gasseri & & & & & & $\checkmark$ \\
\hline
\end{tabular}

BV, bacterial vaginosis; BVAB, bacterial vaginosis-associated bacterium

* The AmpliSens assay was set up to detect the genus Lactobacillus rather than specific species of Lactobacilli. G. vaginalis clades 1 and 2 and $A$. vaginae were detected, and total bacteria for the diagnosis of BV was used.

** An extended version also detects i) Candida albicans, ii) Candida glabrata, iii) Chlamydia trachomatis, iv) Neisseria gonorrhea, and v) Trichomonas vaginalis.

*** Also detects i) T. vaginalis, ii) Candida Group (C. albicans, Candida tropicalis, Candida parapsilosis, and Candida dubliniensis),

iii) C. glabrata, and iv) Candida krusei

Table 6. Characteristics and comparator standards of FDA-approved ${ }^{\S}$ and CE-IVD marked" molecular diagnostic tests (using quantitative multiplex PCR assays) for the diagnosis of BV .

\begin{tabular}{|c|c|c|c|c|c|}
\hline & Sensitivity & Specificity & PPV & NPV & Comparator standard \\
\hline NuSwab $^{52}$ & $96.7 \%$ & $92.2 \%$ & $94 \%$ & $95.6 \%$ & Combination of Amsel and Nugent criteria \\
\hline SureSwab & - & - & - & - & $\begin{array}{l}\text { Results interpreted according to data from } \\
\text { Quest Diagnostics }\end{array}$ \\
\hline $\begin{array}{l}\pi \S \text { BD MAX Vaginal } \\
\text { Panel }\left.\right|^{\star \star 51}\end{array}$ & $90.5-96.2 \%$ & $85.8-96.5 \%$ & $89 \%$ & $87.7 \%$ & $\begin{array}{l}\text { Variably, a number of standards including } \\
\text { Amsel, Nugent, and Ison/Hay criteria, culture, } \\
\text { microbiota analysis, and the Affirm test }\end{array}$ \\
\hline MDL BV Panel ${ }^{53}$ & $99 \%$ & $94 \%$ & $94 \%$ & $94 \%$ & Combination of Amsel and Nugent criteria \\
\hline " AmpliSens* $* 54$ & $97.5 \%$ & $76.8 \%$ & $77.5 \%$ & $97.3 \%$ & $\begin{array}{l}\text { Clinical diagnosis of BV using symptoms, } \\
\text { vaginal } \mathrm{pH} \text {, and wet } \\
\text { mount/Gram stain microscopy }\end{array}$ \\
\hline १ § Hologic Aptima BV***50 & $95-97.3 \%$ & $85.8-92.4 \%$ & - & - & $\begin{array}{l}\text { Nugent criteria (plus Amsel if intermediate } \\
\text { Nugent score) }\end{array}$ \\
\hline
\end{tabular}

BD, Becton Dickinson; BV, bacterial vaginosis; CE-IVD, Conformité Européene in vitro diagnostics; FDA, Food and Drug Administration; MDL, Medical Diagnostics Laboratory; NPV, negative predictive value; PCR, polymerase chain reaction; PPV, positive predictive value

${ }^{*}$ Characteristics of the test are based on a subgroup of symptomatic women

** The range of sensitivities and specificities is derived from a number of different studies that used different standards as comparators

*** Clinician-collected and patient-collected specimens had similar performance

$\S$ FDA approved

If CE-IVD marked

If This table presents separate data from unrelated studies, not comparative differences from a single study or a systematic review or metaanalysis, and does not distinguish between the quality or strength of evidence

not reported, as the complexity of a BV diagnosis is based upon certain indicator organisms and is an example of how the reported result is interpreted according to data from Quest
Diagnostics (Secaucus, NJ, USA) ${ }^{49}$ (see https://testdirectory. questdiagnostics.com/test/test-detail/17333/sureswab-vaginosisvaginitis-plus?cc=MASTER). 
The BD MAX ${ }^{\mathrm{TM}} \mathrm{VP}$ is the first FDA market-authorized, microbiome-based PCR assay that directly detects the three most common infectious causes of vaginitis: i) BV, ii) VVC, and iii) trichomoniasis (also known as TV). For the diagnosis of BV, G. vaginalis, A. vaginae, Megasphaera type-1, and BVAB-2 are used as positive predictors of $\mathrm{BV}$ and L. crispatus and $L$. jensenii are used as negative predictors of BV. The proprietary algorithm provides a laboratory report as positive or negative for BV. The test also detects i) TV, ii) Candida group (C. albicans, Candida tropicalis, Candida parapsilosis, and Candida dubliniensis), iii) C. glabrata, and iv) Candida krusei ${ }^{51}$.

The future also holds hope for new technologies such as machine-learning/artificial intelligence. In a recent study, a machine-learning-based algorithm of seven bacterial strains was measured against the Ison/Hay criteria ${ }^{19}$ and was found to have excellent specificity $(98 \%)$ and NPV $(95 \%)^{55}$.

The MDL BV Panel targeted nine vaginal bacteria as potential markers for BV. Using quantitation and ROC curves, three organisms were chosen as predictors of $\mathrm{BV}$ : i) $G$. vaginalis, ii) A. vaginae, and iii) Megasphaera types 1 and 2. L. crispatus was left out of the final model because it did not contribute to diagnostic accuracy ${ }^{53}$ (see https://www.mdlab.com/forms/ TechBulletin/BV_Panel_Lactobacillus.pdf).

The Hologic Aptima ${ }^{\circledR}$ BV assay is an in vitro NAAT that uses real-time transcription-mediated amplification for the detection and quantitation of ribosomal RNA from bacteria associated with BV. Two organisms were chosen as positive predictors of $\mathrm{BV}$ ( $G$. vaginalis and A. vaginae) and three species of Lactobacilli (L. gasseri, L. crispatus, and L. jensenii) were chosen as negative predictors of $\mathrm{BV}$. The assay reports a qualitative result for $\mathrm{BV}$ rather than results for individual organisms ${ }^{50}$ and is intended to aid in the diagnosis of $\mathrm{BV}$ on the automated Panther ${ }^{\circledR}$ system using clinician- and patient-collected vaginal swabs from women with signs and symptoms of vaginitis and/or vaginosis (see https:/www.hologic.com/hologic-products/ diagnostic-solutions/aptima-vaginal-health).

\section{Tests approved for use in Europe}

To our knowledge, currently in Europe, there are three commercially available molecular diagnostic tests for the diagnosis of BV, all of which are multiplex PCR assays that are CE-IVD marked, are fast, and have a high sensitivity and specificity $^{50,51,54}$. Two of these (BD MAX ${ }^{\mathrm{TM}} \mathrm{VP}$ and Hologic Aptima ${ }^{\circledR}$ BV assays) have already been outlined above. The other is the AmpliSens ${ }^{\circledR}$ (sometimes referred to as the ATRiDA test) Florocenosis/Bacterial vaginosis-FRT PCR test (InterLabService, Moscow, Russia). The AmpliSens ${ }^{\circledR}$ test measures the relative concentration of i) Lactobacillus spp., ii) G. vaginalis clades 1 and 2, iii) A. vaginae, and iv) total bacteria to diagnose BV.

\section{Comparative testing}

The accuracy of a commercially available multiplex PCR (ATRiDA) for the diagnosis of $\mathrm{BV}$ was evaluated in women reporting urogenital symptoms and women notified for STIs who were not necessarily symptomatic. The ATRiDA test
(ATRiDA B.V., Amersfoort, the Netherlands) targets G. vaginalis, A. vaginae, and Lactobacillus spp. in relation to overall bacterial load. The ATRiDA test outcome was compared to the clinical BV diagnosis and to vaginal microbiota composition, determined by $16 \mathrm{~S}$ rRNA gene sequencing, which enables accurate characterization of complex microbial communities with respect to membership and their relative abundance to each other. Based on statistical analyses of vaginal microbiota data, $\mathrm{BV}$ has been defined as $\leq 47 \%$ relative abundance of Lactobacillus spp. and an increased presence of anaerobes. Although recommended by some, microbiota analysis is currently quite laborious and expensive for it to be used routinely in clinical practice ${ }^{56,57}$.

Overall, compared to the clinical BV diagnosis, the ATRiDA test demonstrated high sensitivity $(96.9 \%)$ and moderate specificity $(70.2 \%)$. The NPV was $>97.3 \%$ and the PPV differed by study group but was highest in women reporting urogenital symptoms (78.2\%). 16S rRNA gene sequencing showed that $54 \%$ of women who were ATRiDA BV positive but clinically asymptomatic had a diverse anaerobic vaginal microbiota, classified as asymptomatic vaginal dysbiosis. The authors concluded that the ATRiDA test was a sensitive method for the detection of BV but advised that a positive test should be interpreted in conjunction with clinical symptoms ${ }^{58}$.

Recently, two CE-IVD-marked real-time PCR assays (AmpliSens ${ }^{\circledR}$ and $\mathrm{BD} \mathrm{MAX}^{\mathrm{TM}} \mathrm{VP}$ ) were compared with Amsel criteria, Nugent score, and/or culture for the diagnosis of BV. Microbiota analysis, based on amplicon sequencing of the 16S rRNA gene, described elsewhere ${ }^{59}$, was used as a reference test. Based on the microbiota analysis, the sensitivity of detecting BV was $38.9 \%$ for culture, $61.15 \%$ for Amsel criteria, $63.9 \%$ for Nugent score and the BD MAX ${ }^{\mathrm{TM}}$ VP assay, and $80.6 \%$ for the AmpliSens ${ }^{\circledR}$ assay. The specificity of all methods was $\geq 92.4 \%$. The authors concluded that, compared to Amsel criteria, Nugent score, culture, and the BD MAX ${ }^{\mathrm{TM}}$ VP assay, the AmpliSens ${ }^{\circledR}$ assay offered optimal agreement with microbiota analysis. However, concerns were expressed that the handling of samples was not performed in accordance with the manufacturer's instructions for the BD MAX ${ }^{\mathrm{TM}} \mathrm{VP}$ assay. The eSwabs were tested with the BD $M A^{T M}$ VP assay by pipetting $500 \mu \mathrm{l}$ of eSwab into $500 \mu \mathrm{l}$ of BD MAX ${ }^{\mathrm{TM}}$ Sample Tube Buffer. Although this was done in consultation with $\mathrm{BD}$, it might have influenced the sensitivity of the assay. Furthermore, the report did not describe the advantage of the BD $\mathrm{MAX}^{\mathrm{TM}} \mathrm{VP}$ assay to test for $\mathrm{BV}, \mathrm{VVC}$, and $\mathrm{TV}$ as a single test. For the diagnosis of $\mathrm{VVC}$, the performance of the BD MAX ${ }^{\mathrm{TM}}$ VP assay was comparable to other applied methods and detected additional positive samples compared to the current gold standard (fungal culture). None of the included samples was positive for TV by the applied assays, including the BD MAX ${ }^{\mathrm{TM}}$ $\mathrm{VP}$ assay. One of the classifications was for aerobic vaginitis $(\mathrm{AV})$ as a separate identity from BV, the significance of which, particularly as a predictor of PTB, has been questioned ${ }^{60}$.

Another recent study evaluated the BD MAX ${ }^{\mathrm{TM}} \mathrm{VP}$ for the diagnosis of BV, VVC, and TV. The test was compared with i) a combination of Ison/Hay criteria ${ }^{19}$, the presence of clue 
cells, and a significant growth of $G$. vaginalis, ii) yeast culture, and iii) a combination of culture, wet mount microscopy, and an alternative molecular assay ${ }^{61}$. The sensitivity and specificity for $\mathrm{BV}$ was $89.8 \%$ and $96.5 \%$, respectively. For $\mathrm{TV}$, the sensitivity and specificity were both $100 \%$, and for VVC, the sensitivity and specificity were $97.4 \%$ and $96.8 \%$, respectively. The authors concluded that the BD MAX ${ }^{\mathrm{TM}}$ VP was highly sensitive and specific and simplified the identification of vaginitis of infectious origin.

Finally, in a group of 200 symptomatic women, the performance of the BD MAX ${ }^{\mathrm{TM}} \mathrm{VP}$ was compared to that of the Affirm test, which, for the purpose of the study, was considered to be the standard of care. Both multiplex assays are commercially available for the detection of DNA from organisms associated with vaginitis, including $\mathrm{BV}, \mathrm{VVC}$, and TV. The sensitivity and specificity of the BD MAX ${ }^{\mathrm{TM}} \mathrm{VP}$ for BV was $96.2 \%$ and $96.1 \%$, respectively, compared to $96.2 \%$ and $81.6 \%$, respectively, for the Affirm test. The sensitivity and specificity of the BD MAX ${ }^{\mathrm{TM}}$ VP for VVC was $98.4 \%$ and $95.4 \%$, respectively, compared to $69.4 \%$ and $100 \%$, respectively, for the Affirm test. The BD MAX $^{\mathrm{TM}}$ VP and Affirm test demonstrated $100 \%$ concordance for the detection of TV. The authors concluded that the results demonstrated an improvement in accuracy of the BD MAX ${ }^{\mathrm{TM}}$ $\mathrm{VP}$ compared to the Affirm test for the detection of $\mathrm{BV}$ and $\mathrm{VVC}^{62}$. Using Nugent scoring as a reference, three molecular assays were assessed for the diagnosis of $\mathrm{BV}$, examining the impact of incremental increases in bacterial targeting. The introduction of $A$. vaginae improved specificity for the diagnosis of $\mathrm{BV}$, but co-infection with VVC was common $(13.5 \%)^{63}$, and the shortcomings of molecular-based techniques in the presence of mixed vaginal infections have been emphasized ${ }^{64}$.

In a recent Swedish study of women undergoing termination of pregnancy, BV was determined to be present or absent on the basis of a modified Ison/Hay criteria assessment ${ }^{19}$ and compared with a molecular test analyzing six different bacteria associated with BV (A. vaginae, BVAB-2, G. vaginalis, Leptotrichia/Sneathia spp., Megasphaera spp., and Mobiluncus spp.) in relation to Lactobacillus spp. using real-time PCR. There was excellent agreement between the compared methods, with a kappa coefficient value of 0.87 (0.76-0.99). Compared to the modified Ison/Hay criteria, the molecular test achieved a sensitivity of $91 \%$, specificity of $97 \%$, PPV of $91 \%$, and NPV of $97 \%$.

\section{Emerging techniques and tests}

Microarray analysis and next-generation sequencing (NGS) have contributed to our understanding and development of commercially available tests for BV, but, as yet, these assays are generally performed in large reference laboratories and, outside North America, such as the UK and continental Europe, are not yet commercially available as a routine option ${ }^{49}$.

\section{Use of molecular diagnostic tests in a clinical setting}

Women with symptoms of vaginal dysbiosis may present to their GP, a genitourinary medicine (GUM) clinic, a family planning clinic, or directly to a gynecologist, among whom the services offered and the management and diagnostic skills such as microscopy may differ ${ }^{66}$. The etiology of "the BV syndrome" remains unknown. BV is the most common cause of vaginal discharge globally, with an estimated annual economic burden of $\$ 4.8$ billion $7,67,68$. BV has important public health implications such as PTB and increased risk of acquisition of STIs such as gonorrhea, chlamydia, TV, HSV, and HIV ${ }^{69}$. These are associated with serious mortality and morbidity for women and babies. The place of the condition as a syndrome, together with the proposed potential mechanisms, suggested etiological and predisposing factors, overlying sociodemographic variables, and the different phenotypic outcomes are presented in Figure 1. Though the BV syndrome is certainly sexually associated, being increased in women with i) early sexual debut, ii) greater number of lifetime sexual partners, and iii) introduction of a new sexual partner, increasingly the epidemiology of some subtypes of the BV syndrome supports sexual transmission ${ }^{70}$. At the center of the debate is whether or not BV is caused by a primary pathogen or a polymicrobial, synergistic consortium of microorganisms that are sexually transmitted ${ }^{71}$.

A conceptual model ${ }^{72}$, which was recently updated, suggested that BV originates through the sexual transmission of G. vaginalis $^{73}$. Using its virulence factors, it successfully colonizes the host's vaginal epithelium and forms a biofilm community to overcome Lactobacilli. G. vaginalis's genetic diversity may lead to both pathogenic and non-pathogenic strains. Symbiotic relationships with normally dormant vaginal anaerobes lead to increases in the latter, which contribute to the symptoms of BV. Critics of this model point out that G. vaginalis can be found in a virgo intacta and in sexually active women with a healthy vaginal microbiota and that colonization with $G$. vaginalis does not always lead to $\mathrm{BV}^{74}$, though this has been challenged ${ }^{75}$. Nevertheless, recent research into the pathogenesis of $\mathrm{BV}$ has determined the existence of a number of different species within the Gardnerella genus. It may be that healthy women are colonized by non-pathogenic species of Gardnerella, whereas virulent strains are involved in the development of $\mathrm{BV}^{72}$.

To address this problem, the likelihood of STIs was assessed in symptomatic women tested for vaginal dysbiosis using both the $\mathrm{BD} \mathrm{MAX}^{\mathrm{TM}} \mathrm{VP}$ and the BD MAX ${ }^{\mathrm{TM}} \mathrm{CT} / \mathrm{GC} / \mathrm{TV}$ molecular diagnostic assays. Positivity rates for $C$. trachomatis, N. gonorrhoeae, and TV DNA were calculated, and concordance rates between the assays for the detection of TV were determined. Women with BV alone or with concurrent VVC had high rates of co-infection with STIs (24.4-25.7\%). TV results were concordant between the two assays in 559 of 560 samples tested. These data suggest that women with symptoms of vaginal dysbiosis in the form of BV or candidiasis may be at risk of an STI. Accordingly, molecular testing may provide a broader diagnostic coverage for symptomatic women regardless of the type of clinic in which they are seen ${ }^{76}$.

Symptomatic women attending a GUM clinic in the UK had two vulvovaginal swabs taken. One was used for a chlamydia and gonorrhea NAAT and one for testing on the BD MAX ${ }^{\mathrm{TM}}$ VP. 


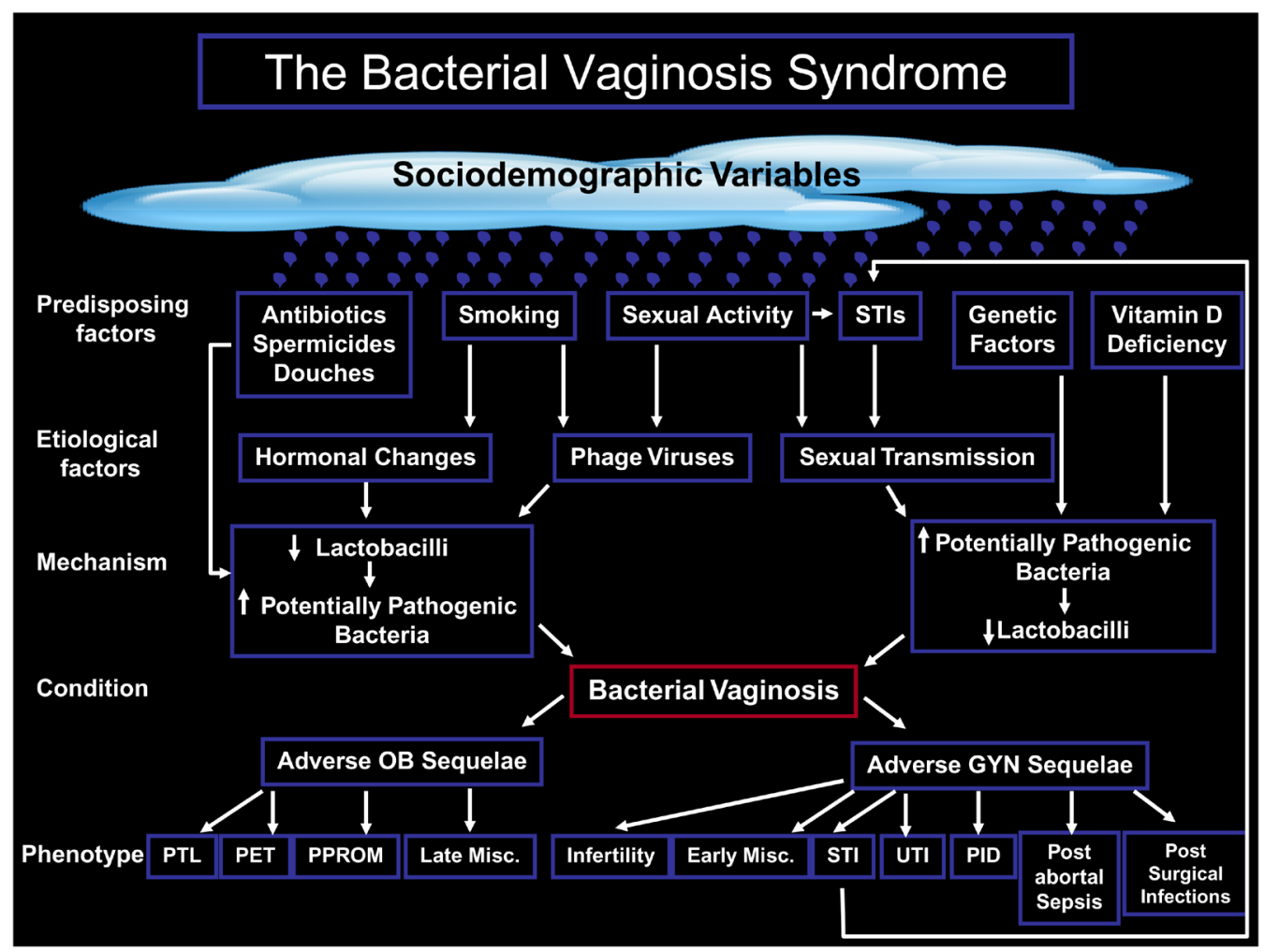

Figure 1. The proposed interaction among the mechanisms, etiology, predisposing factors, and phenotypic outcomes in obstetrics and gynecology of "the bacterial vaginosis syndrome". GYN, gynecological; Misc, miscarriage; OB, obstetric; PET, pre-eclampsia; PID, pelvic inflammatory disease; PPROM, preterm prelabor rupture of the membranes; PTL, preterm labor; STI, sexually transmitted infection; UTI, urinary tract infection.

Speculum examination was then performed and vaginal swabs were taken for vaginal $\mathrm{pH}$ and examination by wet-mount and Gram stain microscopy for VVC, BV, and TV. Forty-six $(23.6 \%)$ women were negative for all three infections on the BD MAX ${ }^{\mathrm{TM}}$ VP. Ninety-three were positive for BV (47.7\%), 70 (35.9\%) for VVC, and 9 (4.6\%) for TV. Thirty-six women tested positive for both BV and VVC on the BD MAX ${ }^{\mathrm{TM}} \mathrm{VP}$. The test sensitivity for VVC was $86.4 \%$ and the specificity was $86.0 \%$. For BV, the sensitivity was $94.4 \%$ and the specificity was $79 \%$. While the sensitivity for BV was encouraging, the specificity was lower than expected. This may reflect the higher rate of STIs in the study population, which worsened the vaginal dysbiosis. The author concluded that while NAATs do not provide immediate results, they were easy to process and offered advantages over a high vaginal swab performed in other settings where rapid microscopic assessment was not readily available ${ }^{77}$. Since such tests are simple, convenient, reliable, and inexpensive, perhaps every woman suspected of having BV should have a simultaneous molecular test (PCR or gene sequencing) for other STIs, albeit this may depend on the patient's risk factors.

\section{Discussion}

Currently, there are a number of diagnostic tests available to diagnose $\mathrm{BV}$, ranging from POCTs to molecular assays. The choice of test will be influenced by the cost, availability, speed, and accuracy of the test. There are few recommendations with respect to the use of molecular-based technology to screen for $\mathrm{BV}$, especially in asymptomatic women ${ }^{49}$. A recently updated ACOG practice bulletin on vaginitis was released ${ }^{78}$ that applied to $\mathrm{BV}, \mathrm{VVC}$, and $\mathrm{TV}$. This still recommends traditional methods for diagnosing vaginitis such as culture, Amsel criteria, and Nugent score. While the bulletin acknowledges that PCR diagnostic tests exist and can be considered for use, it states that they have "comparable sensitivity and specificity to Nugent scoring and Amsel criteria", citing three studies ${ }^{51,61,79}$. However, to justify this statement, at least one of the studies cited actually showed an improvement in performance of NAAT compared to Amsel criteria and clinician diagnosis ${ }^{79}$. Furthermore, a recent study using a different NAAT to test for BV demonstrated a similar improvement compared to Amsel criteria and clinician diagnosis ${ }^{45}$. Many researchers agree that molecular assays are superior to conventional methods such as Amsel, Gram stain, and DNA probes like the Affirm test. What is difficult to explain is why they are not in more widespread use in clinical practice. This is almost certainly a problem in educating the general public, primary care physicians, and specialist clinicians of the potential benefits of these technologies. In the UK, our experience is of academic centers testing 
and validating the technology, following which they are keen to introduce the technology, but a business case has to be made, which takes time with budgets planned a year in advance. In addition, the COVID-19 pandemic has disrupted research, clinical care, and funding in other areas.

In the USA, it is our understanding that the acknowledgement of the benefits of NAATs suffers from the dynamics between regulatory guidelines and payer/reimbursement. While the ACOG guidelines acknowledge the role of NAATs, they do not provide a firm endorsement. Since the funders of healthcare rely heavily on such guidelines, their policies do not support full reimbursement of NAAT for BV. Simultaneous NAAT for STIs is likely to provide further resistance. It is likely to require stronger endorsement in the guidelines of the ACOG or the CDC for NAATs to diagnose BV, TV, VVC, and other STIs to be funded.

This review is designed to increase knowledge about the different molecular assays available, the range of targeted microorganisms, and the test characteristics with respect to sensitivity, specificity, PPV, and NPV. Nevertheless, since BV is a polymicrobial condition, diagnosed (whether by molecular or microscopy techniques) by the presence of potentially dysbiotic organisms and the absence of eubiotic organisms, investigators should avoid the use of direct probe assays of single $\mathrm{BV}$ indicator organisms such as $G$. vaginalis in favor of multiplex PCR technology that is able to detect multiple indicator (or contra-indicatory) organisms.

\section{Nugent's intermediate category}

None of the molecular-based tests discussed address the "intermediate" category on Nugent's score ${ }^{14}$ (grade II; score 4-6), unless they consider that reports such as "unspecified dysbiosis" or "equivocal" or "unclassified" are synonymous for Nugent's intermediate category. It is important to recognize that this intermediate category is a Gram-stain diagnosis, rather than one that is made clinically, and that this category is a distinct entity not only because amalgamation with grade III (BV; Nugent score 7-10) diminishes the specificity and PPV of the Gram-stain for diagnosing BV but also because women with grade II Nugent score often fail to respond to clindamycin, whereas those of grade III do not. Although a distinct entity, the intermediate category is likely to be a transient state on a continuum from a normal microbiota to $\mathrm{BV}$ and vice versa $a^{80,81}$. Our recommendation would be that if the result of the test returns as i) unspecified dysbiosis, ii) equivocal, iii) unclassified, iv) intermediate, or v) indeterminate, repeat the test after a short interval of 10-14 days, and if the result is still unclear and the patient is symptomatic, they should be treated.

\section{L. iners: relative abundance and diversity}

There is increasing interest in the vaginal microbiome as a biomarker for PTB $^{9}$, and $L$. iners may play an important part in the etiology of $\mathrm{PTB}^{9,82,83}$. None of the molecular diagnostic tests discussed above targeted $L$. iners. This is understandable, since the presence or absence of $L$. iners does not differentiate between vaginal eubiosis and dysbiosis. While $L$. iners is commonly found in BV as well as in the eubiotic vagina, it is rare to find one of the other "big three" (L. crispatus, L. jensenii, and L. gasseri) in abundant numbers in the presence of $\mathrm{BV}$ and, conversely, it is rare to find $\mathrm{BV}$ when these three species of Lactobacilli are found in abundance in the presence of minimal diversity of other potentially pathogenic organisms. Nevertheless, the targeting of $L$. iners might improve sensitivity and specificity if the relative abundance of $L$. iners and the diversity of other organisms were known and taken into consideration. In a study of the vaginal microbiome in women with PPROM $^{84}$, using relative abundance and diversity, it was possible to differentiate between the presence of $L$. iners in a eubiotic as well as a dysbiotic vaginal microbiota. In a eubiotic vaginal microbiota, the diversity of organisms is as low as two or three organisms, whereas in $\mathrm{BV}$, the diversity is significantly higher (eight or more) $)^{7}$. In a vaginal microbiota that was dominated by an abundance of $L$. iners, with or without L. crispatus, L. gasseri, or L. jensenii, where there was minimal diversity of other organisms in the microbiota, this could be classified as eubiotic. In contrast, in a vaginal microbiota that was dominated by an abundance of $L$. iners, in the absence of any other species of Lactobacilli, and a high level of diversity (eight or more other potentially pathogenic organisms), this was clearly dysbiotic (unpublished data).

\section{Clades, biovars, and quantitation}

The propensity of $G$. vaginalis, compared to other BV-associated bacteria, to form a biofilm that provides a scaffold to which other potentially pathogenic bacteria can attach ${ }^{85-88}$ may be very important. While the presence or absence of $G$. vaginalis has importance, quantitative analysis is more important with both traditional cultivation-independent ${ }^{89}$ as well as novel molecular-based techniques ${ }^{56}$. These demonstrate that a heavy growth, rather than simply presence or absence, is more predictive of pathology that leads to adverse sequelae ${ }^{56,89}$ and emphasizes the importance of quantitative PCR analysis (see sections on molecular-based techniques and combining A. vaginae and $G$. vaginalis for the diagnosis of $\mathrm{BV}$ above).

Based on enzyme activity and biochemical usage of various sugars, G. vaginalis can be identified as a number of biotypes that render the species phenotypically and genetically heterogeneous. Phenotypic diversity within the species is manifest by i) virulence factors, ii) cytotoxicity, iii) production of lytic enzymes such as vaginolysin and sialidase that break down the local secretory $\operatorname{IgA}$ host response, iv) biofilm formation, v) susceptibility to antibiotics, and vi) adhesion and ability to dislodge species of Lactobacilli from vaginal epithelial cells $^{56}$. Genomic analysis of species of $G$. vaginalis has identified four clades (1-4). A clade is defined as "a group of organisms believed to comprise all the evolutionary descendants of a common ancestor". An example is the Hominids, a clade occupied by humans, chimpanzees, gorillas, orangutans, and gibbons. The four clades of $G$. vaginalis are different with 
respect to genome size and G:C (guanine:cytosine) ratio, sufficient for them to be considered as separate species. In a study that aimed to evaluate the distribution and abundance of the $G$. vaginalis clades and sialidase production, the quantification of all four G. vaginalis clades discriminated between a BV microbiota and a normal microbiota more accurately than measuring $G$. vaginalis sialidase production. Clade 4 was strongly associated with a BV microbiota, despite most clade 4 strains lacking the sialidase A gene. These genetic differences among strains might identify potentially pathogenic from commensal strains of $G$. vaginalis $^{56,90-93}$ and the host's response to each ${ }^{94,95}$. For further information, the reader is guided to an excellent review ${ }^{4}$. These factors may be important in the choice of clades of $G$. vaginalis targeted in molecular-based tests for BV and vaginal dysbiosis ${ }^{54,58}$.

The phenotypic and genotypic variation among strains of $G$. vaginalis may mirror the confusion over the role of the genital mycoplasmas in adverse outcomes of pregnancy ${ }^{89,96}$. Genital species of Ureaplasma are detected frequently in healthy, asymptomatic individuals. Using cultivation-dependent techniques in women delivering between 26 and 34 completed weeks of gestation, $80 \%$ and $24 \%$ of those in spontaneous labor were colonized by Ureaplasma urealyticum and M. hominis, respectively. In contrast, in women not in labor but delivered electively for fetomaternal indications at the same gestational age, $46 \%$ and $8 \%$, respectively, were colonized by U. urealyticum and $M$. hominis ${ }^{89,97}$. This qualitative analysis was significantly different for $U$. urealyticum $(P<0.01)$ but not for $M$. hominis. Nevertheless, when only a heavy colonization of $M$. hominis was considered $\left(>10^{5}\right.$ color change units [the unit of quantity at the time]), 13 women in the study group $(18 \%)$ and none of the controls were identified $(P<0.05)$, suggesting that it was not the presence or absence of the organism that was important but the quantity present ${ }^{89}$. Only certain subtypes of the species are pathogenic. Using molecular-based techniques, it was found that Ureaplasma species consist of 14 serovars from two biovars. The majority of human Ureaplasma isolates belong to Ureaplasma parvum (biovar 1) comprising four serovars (the predominant biovar in patients with genital tract infections), with $U$. urealyticum (biovar 2) comprising 10 serovars isolated much less often. However, the data are limited and conflicted because of the difficulties with traditional genotyping methods ${ }^{98}$. This may be relevant to the confusion about the role of $U$. urealyticum in adverse outcomes of pregnancy ${ }^{96}$.

The genital mycoplasmas have been implicated in a number of adverse outcomes in obstetrics and gynecology, and their role is complicated by the presence or absence of $\mathrm{BV}^{96,99}$. Mycoplasma genitalium is an STI that shares similar clinical aspects with $C$. trachomatis and should be treated if detected. Nevertheless, further research is necessary before M. genitalium is included in molecular-based tests for BV.

\section{Conclusions}

New information from molecular-based cultivation-independent techniques has identified candidate organisms for inclusion in multiplex diagnostic tests. This review presents separate data from unrelated studies, not comparative differences from a single study or a systematic review or meta-analysis. Such diagnostic techniques demonstrate high sensitivities, specificities, PPVs, and NPVs against existing gold-standard diagnostic techniques and will hopefully continue to improve, as our understanding of the vaginal microbiome expands. However, further development and refinement are necessary, and care must be taken when measuring these parameters against different BV diagnostic standards in different molecular diagnostic tests. Testing needs to reflect the importance of the absence of negative markers of BV such as L. crispatus as much as the presence of positive markers such as the combination of G. vaginalis and A. vaginae. They should also take into consideration quantitative as well as qualitative analysis. While they cannot account for rarely detected organisms whose role in the BV syndrome remains unknown, they must continue to study these organisms and make clinicians aware of the false negatives and shortcomings of the test because these organisms may not have been incorporated. It is important to recognize and investigate further the role of $L$. iners in vaginal eubiosis and dysbiosis. Presence or absence is not as important as relative abundance and diversity among other organisms present when differentiating between eubiosis and dysbiosis in the case of $L$. iners. Future tests should recognize and incorporate this anomaly. The choice of primers used for studying the vaginal microbiota has important implications on the evaluation of NGS of the vaginal microbiota using partial $16 \mathrm{~S}$ rRNA gene amplicons and has been discussed elsewhere9. Primers spanning the V3-V4 region identify more taxa in the vaginal microbiota than those from the V1-V2 region, particularly taxa such as G. vaginalis. This is also important when choosing which clade of $G$. vaginalis or biovar of Ureaplasma is being targeted. The future also holds hope for new technologies such as machine-learning and artificial intelligence.

\section{Abbreviations}

$\mathrm{BV}$, bacterial vaginosis; $\mathrm{BVAB}$, bacterial vaginosis-related bacterium; CE-IVD, Conformité Européenne in vitro diagnostic; CST, community state type; FDA, Food and Drug Administration; GAIN, Generating Antibiotic Innovation Now; GP, general practitioner; GUM, genitourinary medicine; HIV, human immunodeficiency virus; HSV, herpes simplex virus; NAAT, nucleic acid amplification test; NGS, next-generation sequencing; NPV, negative predictive value; PCR, polymerase chain reaction; POCT, point of contact test; PPROM, preterm prelabor rupture of the membranes; PPV, positive predictive value; PTB, preterm birth; ROC, receiver operating characteristic; STI, sexually transmitted infection; TV, Trichomonas vaginalis; VP, vaginal panel; VVC, vulvovaginal candidiasis.

\section{Acknowledgements}

The authors would like to thank Ann Lightfoot, Molly Broache, and Devin Gary of Becton, Dickinson and Company and Kimberly Petro of Hologic for their assistance and support with the provision and clarification of scientific information. 
1. Tachedjian G, Aldunate M, Bradshaw CS, et al:: The role of lactic acid production by probiotic Lactobacillus species in vaginal health. Res Microbiol. 2017; 168(9-10): 782-92. PubMed Abstract | Publisher Full Text

2. Ruíz FO, Pascual L, Giordano W, et al:: Bacteriocins and other bioactive substances of probiotic lactobacilli as biological weapons against Neisseria gonorrhoeae. Pathog Dis. 2015; 73(3): ftv013.

PubMed Abstract | Publisher Full Text

3. González-Escalona N, Allard MA, Brown EW, et al.: Nanopore sequencing for fast determination of plasmids, phages, virulence markers, and antimicrobia resistance genes in Shiga toxin-producing Escherichia coli. PLOS One. 2019; 14(7): e0220494. PubMed Abstract | Publisher Full Text | Free Full Text

4. Castro J, Jefferson KK, Cerca N: Genetic Heterogeneity and Taxonomic Diversity among Gardnerella Species. Trends Microbiol. 2020; 28(3): 202-11. PubMed Abstract | Publisher Full Text | Faculty Opinions Recommendation

5. Holm JB, France MT, Ma B, et al.: Comparative Metagenome-Assembled Genome Analysis of "Candidatus Lachnocurva vaginae", Formerly Known as Bacterial Vaginosis-Associated Bacterium-1 (BVAB1). Front Cell Infect Microbiol. 2020; 10: 117.

PubMed Abstract | Publisher Full Text | Free Full Text

Faculty Opinions Recommendation

6. Austin MN, Rabe LK, Srinivasan S, et al.: Mageeibacillus indolicus gen. nov., sp. nov.: A novel bacterium isolated from the female genital tract. Anaerobe. 2015; 32: 37-42.

PubMed Abstract | Publisher Full Text | Free Full Text

7. Lamont RF, Sobel JD, Akins RA, et al:: The vaginal microbiome: New information about genital tract flora using molecular based techniques. BJOG. 2011; 118(5): 533-49.

PubMed Abstract | Publisher Full Text | Free Full Text

8. Ravel J, Gajer P, Abdo Z, et al:: Vaginal microbiome of reproductive-age women. Proc Natl Acad Sci U S A. 2011; 108 Suppl 1(Suppl 1): 4680-7. PubMed Abstract | Publisher Full Text | Free Full Text | Faculty Opinions Recommendation

9. Peelen MJ, Luef BM, Lamont RF, et al.: The influence of the vaginal microbiota on preterm birth: A systematic review and recommendations for a minimum dataset for future research. Placenta. 2019; 79: 30-9. PubMed Abstract | Publisher Full Text

10. Gardner $\mathrm{HL}$, Dukes $\mathrm{CD}$ : Haemophilus vaginalis vaginitis: a newly defined specific infection previously classified non-specific vaginitis. Am J Obstet Gynecol. 1955; 69(5): 962-76.

PubMed Abstract | Publisher Full Text

11. Lamont RF: Advances in the Prevention of Infection-Related Preterm Birth. Front Immunol. 2015; 6: 566.

PubMed Abstract | Publisher Full Text | Free Full Text

Faculty Opinions Recommendation

12. Lamont RF, Morgan DJ, Wilden SD, et al.: Prevalence of bacterial vaginosis in women attending one of three general practices for routine cervical cytology. Int J STD AIDS. 2000; 11(8): 495-8.

PubMed Abstract | Publisher Full Text

13. Amsel R, Totten PA, Spiegel CA, et al:: Nonspecific vaginitis. Diagnostic criteria and microbial and epidemiologic associations. Am J Med. 1983; 74(1): 14-22. PubMed Abstract | Publisher Full Text

14. Nugent RP, Krohn MA, Hillier SL: Reliability of diagnosing bacterial vaginosis is improved by a standardized method of gram stain interpretation. J Clin Microbiol. 1991; 29(2): 297-301.

PubMed Abstract | Publisher Full Text | Free Full Text

15. Donders GGG, Vereecken A, Bosmans E, et al:: Definition of a type of abnormal vaginal flora that is distinct from bacterial vaginosis: Aerobic vaginitis. BJOG. 2002; 109(1): 34-43.

PubMed Abstract | Publisher Full Text

16. Lamont RF, Hudson EA, Hay PE, et al:: A comparison of the use of Papanicolaou-stained cervical cytological smears with Gram-stained vaginal smears for the diagnosis of bacterial vaginosis in early pregnancy. Int J STD AIDS. 1999; 10(2): 93-7.

PubMed Abstract | Publisher Full Text

17. Spiegel CA, Amsel R, Holmes KK: Diagnosis of bacterial vaginosis by direct gram stain of vaginal fluid. J Clin Microbiol. 1983; 18(1): 170-7. PubMed Abstract | Publisher Full Text | Free Full Text

18. Hay PE, Taylor-Robinson D, Lamont RF: Diagnosis of bacterial vaginosis in a gynaecology clinic. Br J Obstet Gynaecol. 1992; 99(1): 63-6. PubMed Abstract | Publisher Full Text

19. Ison $\mathrm{CA}$, Hay PE: Validation of a simplified grading of Gram stained vaginal smears for use in genitourinary medicine clinics. Sex Transm Infect. 2002; 78(6): 413-5.

PubMed Abstract | Publisher Full Text | Free Full Text

20. Schmidt $\mathrm{H}$, Hansen JG: Diagnosis of bacterial vaginosis by wet mount identification of bacterial morphotypes in vaginal fluid. Int J STD AIDS. 2000; 11(3): 150-5.

PubMed Abstract | Publisher Full Text

21. Cauci S, Driussi S, Monte R, et al.: Immunoglobulin A response against Gardnerella vaginalis hemolysin and sialidase activity in bacterial vaginosis. Am J Obstet Gynecol. 1998; 178(3): 511-5.

PubMed Abstract | Publisher Full Text

22. Myziuk L, Romanowski B, Johnson SC: BVBlue test for diagnosis of bacterial vaginosis. J Clin Microbiol. 2003; 41(5): 1925-8.

PubMed Abstract | Publisher Full Text | Free Full Text

23. O'Dowd TC, West RR, Winterburn PJ, et al.: Evaluation of a rapid diagnostic test for bacterial vaginosis. Br J Obstet Gynaecol. 1996; 103(4): 366-70.

PubMed Abstract | Publisher Full Text

24. Thomason JL, Gelbart SM, Wilcoski LM, et al.: Proline aminopeptidase activity as a rapid diagnostic test to confirm bacterial vaginosis. Obstet Gynecol. 1988; 71(4): 607-11.

PubMed Abstract

25. Thomason JL, Gelbart SM, James JA, et al:: Is analysis of vaginal secretions for volatile organic acids to detect bacterial vaginosis of any diagnostic value? Am J Obstet Gynecol. 1988; 159(6): 1509-11.

PubMed Abstract | Publisher Full Text

26. Wolrath $\mathrm{H}$, Forsum U, Larsson PG, et al.: Analysis of bacterial vaginosis-related amines in vaginal fluid by gas chromatography and mass spectrometry. $J$ Clin Microbiol. 2001; 39(11): 4026-31.

PubMed Abstract | Publisher Full Text | Free Full Text

27. McDonald HM, O'Loughlin JA, Jolley $\mathrm{P}$, et al:: Prenatal microbiological risk factors associated with preterm birth. Br J Obstet Gynaecol. 1992; 99(3): 190-6. PubMed Abstract | Publisher Full Text

28. Eschenbach DA, Hillier $S$, Critchlow $C$, et al.: Diagnosis and clinical manifestations of bacterial vaginosis. Am J Obstet Gynecol. 1988; 158(4): 819-28. PubMed Abstract | Publisher Full Text

29. Hoyme UB, Saling E: Efficient prematurity prevention is possible by $\mathrm{pH}$-self measurement and immediate therapy of threatening ascending infection. Eur $J$ Obstet Gynecol Reprod Biol. 2004; 115(2): 148-53. PubMed Abstract | Publisher Full Text

30. Hay P, Tummon A, Ogunfile M, et al.: Evaluation of a novel diagnostic test for bacterial vaginosis: 'the electronic nose'. Int J STD AIDS. 2003; 14(2): 114-8. PubMed Abstract | Publisher Full Text

31. Verstraelen $\mathrm{H}$, Verhelst $\mathrm{R}$ : Bacterial vaginosis: An update on diagnosis and treatment. Expert Rev Anti Infect Ther. 2009; 7(9): 1109-24. PubMed Abstract | Publisher Full Text

32. Bradshaw CS, Morton AN, Garland SM, et al.: Evaluation of a point-of-care test, BVBlue, and clinical and laboratory criteria for diagnosis of bacterial vaginosis. J Clin Microbiol. 2005; 43(3): 1304-8. PubMed Abstract | Publisher Full Text | Free Full Text

33. Cartwright $\mathrm{CP}$, Pherson AJ, Harris $\mathrm{AB}$, et al:: Multicenter study establishing the clinical validity of a nucleic-acid amplification-based assay for the diagnosis of bacterial vaginosis. Diagn Microbiol Infect Dis. 2018; 92(3): 173-8. PubMed Abstract | Publisher Full Text | Faculty Opinions Recommendation

34. Donders GGG, Ravel J, Vitali B, et al.: Role of Molecular Biology in Diagnosis and Characterization of Vulvo-Vaginitis in Clinical Practice. Gynecol Obstet Invest. 2017; 82(6): 607-616.

PubMed Abstract | Publisher Full Text

35. Machado A, Cerca N: Multiplex Peptide Nucleic Acid Fluorescence In Situ Hybridization (PNA-FISH) for Diagnosis of Bacterial Vaginosis. Methods Mol Biol. 2017; 1616: 209-19.

PubMed Abstract | Publisher Full Text

36. Plummer EL, Garland SM, Bradshaw CS, et al:: Molecular diagnosis of bacteria vaginosis: Does adjustment for total bacterial load or human cellular content improve diagnostic performance? J Microbiol Methods. 2017; 133: 66-8. PubMed Abstract | Publisher Full Text

37. Pandya S, Ravi K, Srinivas V, et al:: Comparison of culture-dependent and culture-independent molecular methods for characterization of vaginal microflora. J Med Microbiol. 2017; 66(2): 149-53.

PubMed Abstract | Publisher Full Text | Free Full Text

38. Fredricks DN, Fiedler TL, Marrazzo JM: Molecular identification of bacteria associated with bacterial vaginosis. N Engl J Med. 2005; 353(18): 1899-911. PubMed Abstract | Publisher Full Text | Faculty Opinions Recommendation

39. Fredricks DN, Fiedler TL, Thomas KK, et al:: Targeted PCR for detection of vaginal bacteria associated with bacterial vaginosis. J Clin Microbiol. 2007; 45(10): 3270-6.

PubMed Abstract | Publisher Full Text | Free Full Text |

Faculty Opinions Recommendation

40. Menard JP, Fenollar F, Henry M, et al:: Molecular quantification of Gardnerella vaginalis and Atopobium vaginae loads to predict bacterial vaginosis. Clin Infect Dis. 2008; 47(1): 33-43.

PubMed Abstract | Publisher Full Text 
41. Kazor CE, Mitchell PM, Lee AM, et al.: Diversity of bacterial populations on the tongue dorsa of patients with halitosis and healthy patients. $J$ Clin Microbiol. 2003; 41(2): 558-63.

PubMed Abstract | Publisher Full Text | Free Full Text

42. Eschenlauer SCP, McKain N, Walker ND, et al:: Ammonia production by rumina microorganisms and enumeration, isolation, and characterization of bacteria capable of growth on peptides and amino acids from the sheep rumen. Appl Environ Microbiol. 2002; 68(10): 4925-31.

PubMed Abstract | Publisher Full Text | Free Full Text

43. Kumar PS, Griffen AL, Barton JA, et al:: New bacterial species associated with chronic periodontitis. J Dent Res. 2003; 82(5): 338-44.

PubMed Abstract | Publisher Full Text

44. Burton JP, Devillard E, Cadieux PA, et al.: Detection of Atopobium vaginae in postmenopausal women by cultivation-independent methods warrants further investigation. J Clin Microbiol. 2004; 42(4): 1829-31. PubMed Abstract | Publisher Full Text | Free Full Text

45. Trama JP, Pascal KE, Zimmerman J, et al.: Rapid detection of Atopobium vaginae and association with organisms implicated in bacterial vaginosis. Mol Cell Probes. 2008; 22(2): 96-102.

PubMed Abstract | Publisher Full Text

46. Verhelst $\mathrm{R}$, Verstraelen $\mathrm{H}$, Claeys $\mathrm{G}$, et al.: Cloning of 16S rRNA genes amplified from normal and disturbed vaginal microflora suggests a strong association between Atopobium vaginae, Gardnerella vaginalis and bacterial vaginosis. BMC Microbiol. 2004; 4: 16.

PubMed Abstract | Publisher Full Text | Free Full Text

47. Bradshaw CS, Tabrizi SN, Fairley CK, et al:: The association of Atopobium vaginae and Gardnerella vaginalis with bacterial vaginosis and recurrence after oral metronidazole therapy. J Infect Dis. 2006; 194(6): 828-36. PubMed Abstract | Publisher Full Text | Faculty Opinions Recommendation

48. Klindworth A, Pruesse E, Schweer T, et al:: Evaluation of general 16S ribosomal RNA gene PCR primers for classical and next-generation sequencing-based diversity studies. Nucleic Acids Res. 2013; 41(1): e1. PubMed Abstract | Publisher Full Text | Free Full Text

49. Coleman JS, Gaydos CA: Molecular Diagnosis of Bacterial Vaginosis: An Update. J Clin Microbiol. 2018; 56(9): e00342-18. PubMed Abstract | Publisher Full Text | Free Full Text | Faculty Opinions Recommendation

50. N Schwebke JR, Taylor SN, Ackerman R, et al: Clinical Validation of the Aptima Bacterial Vaginosis and Aptima Candida/Trichomonas Vaginitis Assays: Results from a Prospective Multicenter Clinical Study. J Clin Microbiol. 2020; 58(2): e01643-19.

PubMed Abstract | Publisher Full Text | Free Full Text |

Faculty Opinions Recommendation

51. Gaydos CA, Beqaj S, Schwebke JR, et al:: Clinical Validation of a Test for the Diagnosis of Vaginitis. Obstet Gynecol. 2017; 130(1): 181-9. PubMed Abstract | Publisher Full Text | Free Full Text

52. Cartwright $\mathrm{CP}$, Lembke BD, Ramachandran K, et al.: Development and validation of a semiquantitative, multitarget PCR assay for diagnosis o bacterial vaginosis. J Clin Microbiol. 2012; 50(7): 2321-9. PubMed Abstract | Publisher Full Text | Free Full Text | Faculty Opinions Recommendation

53. Hilbert DW, Smith WL, Chadwick SG, et al.: Development and Validation of a Highly Accurate Quantitative Real-Time PCR Assay for Diagnosis of Bacterial Vaginosis. J Clin Microbiol. 2016; 54(4): 1017-24. PubMed Abstract | Publisher Full Text | Free Full Text

54. Rumyantseva T, Shipitsyna E, Guschin A, et al: Evaluation and subsequent optimizations of the quantitative AmpliSens Florocenosis/Bacterial vaginosisFRT multiplex real-time PCR assay for diagnosis of bacterial vaginosis. APMIS. 2016; 124(12): 1099-108.

PubMed Abstract | Publisher Full Text

55. D Drew RJ, Murphy T, Broderick D, et al:: An interpretation algorithm for molecular diagnosis of bacterial vaginosis in a maternity hospital using machine learning: Proof-of-concept study. Diagn Microbiol Infect Dis. 2020; 96(2): 114950 .

PubMed Abstract | Publisher Full Text | Faculty Opinions Recommendation

56. Shipitsyna $E$, Roos $A$, Datcu $R$, et al:: Composition of the vaginal microbiota in women of reproductive age--sensitive and specific molecular diagnosis of bacterial vaginosis is possible? PLOS One. 2013; 8(4): e60670. PubMed Abstract | Publisher Full Text | Free Full Text

57. Macklaim JM, Cohen CR, Donders G, et al.: Exploring a road map to counter misconceptions about the cervicovaginal microbiome and disease. Reprod Sci. 2012; 19(11): 1154-62.

PubMed Abstract | Publisher Full Text | Free Full Text

58. N van der Veer C, van Houdt R, van Dam A, et al:: Accuracy of a commercial multiplex PCR for the diagnosis of bacterial vaginosis. J Med Microbiol. 2018; 67(9): 1265-70.

PubMed Abstract | Publisher Full Text | Free Full Text

Faculty Opinions Recommendation

59. van den Munckhof EHA, van Sitter RL, Boers KE, et al:: Comparison of Amsel criteria, Nugent score, culture and two CE-IVD marked quantitative real-time PCRs with microbiota analysis for the diagnosis of bacterial vaginosis. Eur $J$
Clin Microbiol Infect Dis. 2019; 38(5): 959-66.

PubMed Abstract | Publisher Full Text

60. Lamont RF, Taylor-Robinson D: The role of bacterial vaginosis, aerobic vaginitis, abnormal vaginal flora and the risk of preterm birth. BJOG. 2010; 117(1): 119-20. author reply $120-1$

PubMed Abstract | Publisher Full Text

61. Aguirre-Quiñonero A, Castillo-Sedano ISd, Calvo-Muro F, et al:: Accuracy of the BD MAX'M vaginal panel in the diagnosis of infectious vaginitis. Eur J Clin Microbiol Infect Dis. 2019; 38(5): 877-82.

PubMed Abstract | Publisher Full Text | Faculty Opinions Recommendation

62. Nhompson A, Timm K, Borders N, et al.: Diagnostic performance of two molecular assays for the detection of vaginitis in symptomatic women. Eur $J$ Clin Microbiol Infect Dis. 2020; 39(1): 39-44.

PubMed Abstract | Publisher Full Text | Free Full Text Faculty Opinions Recommendation

63. Richter SS, Otiso J, Goje OJ, et al.: Prospective Evaluation of Molecular Assays for Diagnosis of Vaginitis. J Clin Microbiol. 2019; 58(1): e01264-19. PubMed Abstract | Publisher Full Text | Free Full Text |

Faculty Opinions Recommendation

64. Lynch T, Peirano G, Lloyd T, et al:: Molecular Diagnosis of Vaginitis: Comparing Quantitative PCR and Microbiome Profiling Approaches to Current Microscopy Scoring. J Clin Microbiol. 2019; 57(9): e00300-19.

PubMed Abstract | Publisher Full Text | Free Full Text |

Faculty Opinions Recommendation

65. Breding K VI, Selbing A, Farnebäck M, et al.: Diagnosis of Bacterial Vaginosis Using a Novel Molecular Real-Time PCR Test. J Women's Health Gyn. 2020; 7: $1-7$ Reference Source

66. Paton SL, Fernando I, Lamont RF: A comparison of sexual and reproductive health services provided by genitourinary and family planning clinics for adolescents. Int J STD AIDS. 2010; 21(9): 642-7.

PubMed Abstract | Publisher Full Text

67. Peebles K, Velloza J, Balkus JE, et al:: High Global Burden and Costs of Bacterial Vaginosis: A Systematic Review and Meta-Analysis. Sex Transm Dis. 2019; 46: 304-11.

PubMed Abstract | Publisher Full Text | Faculty Opinions Recommendation

68. Anderson MR, Klink K, Cohrssen A: Evaluation of vaginal complaints. JAMA. 2004; 291(11): 1368-79.

PubMed Abstract | Publisher Full Text

69. Balkus JE, Manhart LE, Lee J, et al.: Periodic Presumptive Treatment for Vaginal Infections May Reduce the Incidence of Sexually Transmitted Bacterial Infections. J Infect Dis. 2016; 213(12): 1932-7.

PubMed Abstract | Publisher Full Text | Free Full Text

70. Muzny CA, Schwebke JR: Pathogenesis of Bacterial Vaginosis: Discussion of Current Hypotheses. J Infect Dis. 2016; 214 Suppl 1(Suppl 1): S1-5. PubMed Abstract | Publisher Full Text | Free Full Text |

Faculty Opinions Recommendation

71. Wilson JD: Bacterial vaginosis: going full circle? Sex Transm Infect. 2017; 93(3) 220.

PubMed Abstract | Publisher Full Text

72. Schwebke JR, Muzny CA, Josey WE: Role of Gardnerella vaginalis in the pathogenesis of bacterial vaginosis: a conceptual model. J Infect Dis. 2014; 210(3): 338-43.

PubMed Abstract | Publisher Full Text | Faculty Opinions Recommendation

73. Muzny CA, Taylor CM, Swords WE, et al.: An Updated Conceptual Model on the Pathogenesis of Bacterial Vaginosis. J Infect Dis. 2019; 220(9): 1399-405. PubMed Abstract | Publisher Full Text | Free Full Text |

Faculty Opinions Recommendation

74. Hickey RJ, Forney LJ: Gardnerella vaginalis does not always cause bacterial vaginosis. J Infect Dis. 2014; 210(10): 1682-3.

PubMed Abstract | Publisher Full Text | Free Full Text

75. Schwebke JR, Muzny CA, Josey WE: Reply to Hickey and Forney. J Infect Dis. 2014; 210(10): 1683-4.

PubMed Abstract | Publisher Full Text

76. Vvan der Pol B, Daniel G, Kodsi S, et al:: Molecular-based Testing for Sexually Transmitted Infections Using Samples Previously Collected for Vaginitis Diagnosis. Clin Infect Dis. 2019; 68(3): 375-81.

PubMed Abstract | Publisher Full Text | Free Full Text |

Faculty Opinions Recommendation

77. Sherrard J: Evaluation of the BD MAX ${ }^{\mathrm{TM}}$ Vaginal Panel for the detection of vaginal infections in a sexual health service in the UK. Int J STD AIDS. 2019; 30(4): 411-4.

PubMed Abstract | Publisher Full Text | Faculty Opinions Recommendation

78. Committee on Practice Bulletins-Gynecology: Vaginitis in Nonpregnant Patients: ACOG Practice Bulletin, Number 215. Obstet Gynecol. 2020; 135(1) e1-e17.

PubMed Abstract | Publisher Full Text | Faculty Opinions Recommendation

79. N Schwebke JR, Gaydos CA, Nyirjesy P, et al:: Diagnostic Performance of a Molecular Test versus Clinician Assessment of Vaginitis. J Clin Microbiol. 2018; 
56(6): e00252-18.

PubMed Abstract | Publisher Full Text | Free Full Text |

Faculty Opinions Recommendation

80. Lamont RF, Taylor-Robinson D: Review of the accuracy of various diagnostic tests for bacterial vaginosis to predict preterm birth (Honest et al., BJOG, May 2004). BJOG. 2005; 112(2): 259-60; author reply 260-1. PubMed Abstract | Publisher Full Text

81. Taylor-Robinson D, Morgan DJ, Sheehan M, et al.: Relation between Gram-stain and clinical criteria for diagnosing bacterial vaginosis with special reference to Gram grade II evaluation. Int J STD AIDS. 2003; 14(1): 6-10. PubMed Abstract | Publisher Full Text

82. Kindinger LM, Bennett PR, Lee YS, et al:: The interaction between vagina microbiota, cervical length, and vaginal progesterone treatment for preterm birth risk. Microbiome. 2017; 5(1): 6 .

PubMed Abstract | Publisher Full Text | Free Full Text

83. Petricevic L, Domig KJ, Nierscher FJ, et al.: Characterisation of the vaginal Lactobacillus microbiota associated with preterm delivery. Sci Rep. 2014; 4: 5136.

PubMed Abstract | Publisher Full Text | Free Full Text

84. Kacerovsky M, Vrbacky F, Kutova R, et al.: Cervical microbiota in women with preterm prelabor rupture of membranes. PLoS One. 2015; 10(5): e0126884. PubMed Abstract | Publisher Full Text | Free Full Text

85. Patterson JL, Stull-Lane A, Girerd PH, et al: Analysis of adherence, biofilm formation and cytotoxicity suggests a greater virulence potential of Gardnerella vaginalis relative to other bacterial-vaginosis-associated anaerobes. Microbiology (Reading). 2010; 156(Pt 2): 392-9. PubMed Abstract | Publisher Full Text | Free Full Text

86. Castro J, Machado D, Cerca N: Unveiling the role of Gardnerella vaginalis in polymicrobial Bacterial Vaginosis biofilms: the impact of other vaginal pathogens living as neighbors. ISME J. 2019; 13(5): 1306-17. PubMed Abstract | Publisher Full Text | Free Full Text | Faculty Opinions Recommendation

87. Castro J, Rosca AS, Cools P, et al:: Gardnerella vaginalis Enhances Atopobium vaginae Viability in an in vitro Model. Front Cell Infect Microbiol. 2020; 10: 83.

PubMed Abstract | Publisher Full Text | Free Full Text Faculty Opinions Recommendation

88. Nisha K, Antony B, Udayalaxmi J: Comparative analysis of virulence factor \& biotypes of Gardnerella vaginalis isolated from the genital tract of women with \& without bacterial vaginosis. Indian J Med Res. 2019; 149(1): 57-61. PubMed Abstract | Publisher Full Text | Free Full Text | Faculty Opinions Recommendation

89. Lamont RF, Taylor-Robinson D, Wigglesworth JS, et al.: The role of mycoplasmas, ureaplasmas and chlamydiae in the genital tract of women presenting in spontaneous early preterm labour. J Med Microbiol. 1987; 24(3): 253-7. PubMed Abstract | Publisher Full Text
90. Cornejo OE, Hickey RJ, Suzuki H, et al: Focusing the diversity of Gardnerella vaginalis through the lens of ecotypes. Evol Appl. 2018; 11(3): 312-24. PubMed Abstract | Publisher Full Text | Free Full Text | Faculty Opinions Recommendation

91. Janulaitiene M, Paliulyte V, Grinceviciene S, et al:: Prevalence and distribution of Gardnerella vaginalis subgroups in women with and without bacterial vaginosis. BMC Infect Dis. 2017; 17(1): 394 PubMed Abstract | Publisher Full Text | Free Full Text

92. Shipitsyna E, Krysanova A, Khayrullina G, et al:: Quantitation of all Four Gardnerella vaginalis Clades Detects Abnormal Vaginal Microbiota Characteristic of Bacterial Vaginosis More Accurately than Putative G. vaginalis Sialidase A Gene Count. Mol Diagn Ther. 2019; 23(1): 139-47. PubMed Abstract | Publisher Full Text | Free Full Text | Faculty Opinions Recommendation

93. Robinson LS, Schwebke J, Lewis WG, et al:: Identification and characterization of $\mathrm{NanH} 2$ and $\mathrm{NanH} 3$, enzymes responsible for sialidase activity in the vaginal bacterium Gardnerella vaginalis. J Biol Chem. 2019; 294(14): 5230-45

PubMed Abstract | Publisher Full Text | Free Full Text | Faculty Opinions Recommendation

94. Castro J, Jefferson KK, Cerca N: Innate immune components affect growth and virulence traits of bacterial-vaginosis-associated and non-bacterialvaginosis-associated Gardnerella vaginalis strains similarly. Pathog Dis. 2018 76(9).

PubMed Abstract | Publisher Full Text | Faculty Opinions Recommendation

95. Hourigan SK, Subramanian P, Hasan NA, et al.: Comparison of Infant Gut and Skin Microbiota, Resistome and Virulome Between Neonatal Intensive Care Unit (NICU) Environments. Front Microbiol. 2018; 9: 1361 PubMed Abstract | Publisher Full Text | Free Full Text | Faculty Opinions Recommendation

96. Taylor-Robinson D, Lamont RF: Mycoplasmas in pregnancy. BJOG. 2011; 118(2): $164-74$.

PubMed Abstract | Publisher Full Text

97. Lamont RF, Taylor-Robinson D, Newman M, et al.: Spontaneous early preterm labour associated with abnormal genital bacterial colonization. $\mathrm{Br} J$ Obstet Gynaecol. 1986; 93(8): 804-10.

PubMed Abstract | Publisher Full Text

98. Dhawan B, Malhotra N, Sreenivas V, et al:: Ureaplasma serovars \& their antimicrobial susceptibility in patients of infertility \& genital tract infections. Indian J Med Res. 2012; 136(6): 991-6. PubMed Abstract | Free Full Text

99. Molenaar MC, Singer M, Ouburg S: The two-sided role of the vaginal microbiome in Chlamydia trachomatis and Mycoplasma genitalium pathogenesis. J Reprod Immunol. 2018; 130: 11-7.

PubMed Abstract | Publisher Full Text | Faculty Opinions Recommendation 